\title{
Characterization of Taoura's multilayers system by the geochemical tracers of carbonates and the evaporites (oriental extreme Algeria).
}

\author{
Yasmina Bouroubi Ouadfel and Mounira Djebbar
}

\author{
Department of Earth Sciences. Faculty of Earth Sciences, Geography and Spatial Planning, \\ University Mentouri, Route Ain El Bey, 25010 Constantine- Algeria. \\ yasmina.bouroubi@yahoo.fr Mob/ Tel: 00213553145 514.djebbare@yahoo.fr
}

\begin{abstract}
In the North-East Algeria, in the zone of diapirs, the previous hydrogeologic study of the region of Souk-Ahras Taoura had identified the multilayer aquifer system of Miocene sandstones and carbonates of lower and upper Cretaceous. The formations are generally dominated by carbonate intercalated with marl, highly fractured and folded (NE-SW), in parallel to the direction of the structures outcrops the Triassic diapiric. The thermal carbonated aquifer updates of the Neogene-quaternary of highly mineralized springs with low discharge (Hammam Tassa, Ain El Damssa); the fissural aquifer and the maastrichtian and campanian aquifers, widely exploited for the drinking water and the irrigation, contain an important potential in water. For a better understanding of the functioning of the aquifer system, it seemed necessary to characterize him by geochemical tracers of carbonates and evaporates. The geochemical data of waters of sources and main drillings showed, on one hand that thermal waters circulated rather profoundly by washing the Triassic evaporitic, and on the other hand which the fracturing in distension allowed waters to drain simultaneously aquifers. Thus, waters appearing to springs would be a mixture, in variable proportions, between the different types of water flowing in this hydrothermal karst system.
\end{abstract}

Keywords: North-East Algeria, Cretaceous Carbonate, Triassic diapiric, Thermal, Mixture of water.

\section{INTRODUCTION}

In the North-East extreme of Algeria, karstified carbonate formations update thermomineral water with varying temperatures $\left(24-98^{\circ} \mathrm{C}\right)$, the synclinal basin of Souk-Ahras Taoura belongs to this province. The studies for this region are very limited and include the spa waters in regional context Guigue (1947), Dib (1985), Rezig et al. (1995). Very recent work, Bouroubi (2009), (Bouroubi and Djebbar, 2011), focused on the entity hydrogeological of SoukAhras Taoura have identified the circulation of vast underground karst aquifer system. In this work we present the main results supplemented by geochemical tracers of carbonates and evaporites.

Geographical context: The concerned region is situated between the Tell Atlas and Saharan Atlas, the Tunisian-Algerian border (Fig. 1). Covering an area of $1400 \mathrm{~km}^{2}$, the basin is subjected to a semiarid climate clearly where the average temperature of the air is $15.6^{\circ} \mathrm{C}$, and rainfall is erratic $(550 \mathrm{~mm} /$ year $)$.

In this climate zone, winters are very cold and wet with snow estimated at 8-10 days between December and March, and the summers are very hot and dry with high evaporating power (74\%). 


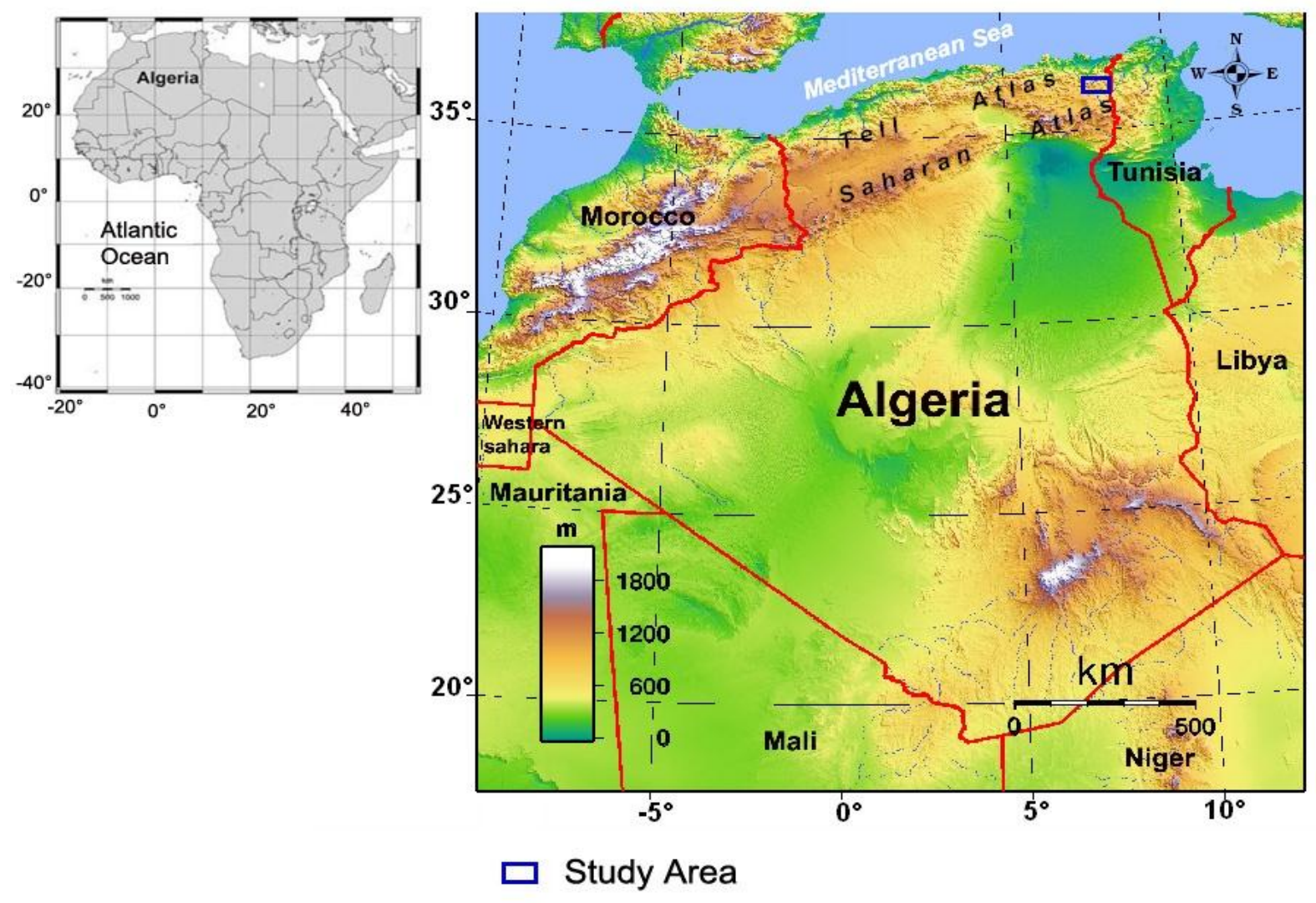

Fig. 1. Location of Algeria in Africa. The blue rectangle represents study area.

Geological and hydrogeological context: The basin of Souk-Ahras Taoura belongs to the zone of diapirs eastern Algeria. This parautochthonous or autochthonous area Vila (1980) retained the inherited structure of the final phase Eocene tectonics. In this domain of the north "country-atlasic", where the Jurassic is absent, the vast folded structures SW-NE are lined with large masses of Triassic and are intensely affected by normal faults (Fig.2)

Triasic complex: Recent work on the mining geology of El Ouasta anticline and Triassic of SoukAhras Haddouche (2003), Baaouague (2010) relate a detailed petrographic description of Triassic diapiric sector of the basin Souk-Ahras Taoura. According to this study, the Triassic formations consist mainly of marls and variegated clays containing a variety of evaporate minerals. Brecciated carbonate formations of the dissolution bordering clay-gypsum insert all different materials. There are blocks of gray dolomite, limestone in plaques, sandstone and the Ophites (highly altered rocks of volcanic origin). The breccia formations also contain minerals sulfated (celestite, barite), silicates (quartz, white mica), sulfides and oxides, iron hydroxides. Among the sulfate minerals of the transition zone, the sulfate gypsum represent the least abundant, the late character of this mineral come from the alteration of anhydrite in the surface regions by hydration, from meteoric water.

Furthermore, the mineral phases are characteristic of the subsiding series and at several stages of evolution (Process of replacement and transformation) from the renewed circulation of hydrothermal fluids.

Cretaceous: The Cretaceous formations begin with marly sandstone deposits (Barremian and Aptian). These sediments are succeeded calcareous benches (50 - 250m) alternated by marls or by marlslimestones which can affect $150 \mathrm{~m}$ of thickness. The upper Cretaceous (Senonian) is chalky.

Paleocene-Eocene: They are characterized by marls and contain little thick limestones benches of with intercalations of sandstones and conglomerates. North of the region of Souk-Ahras Taoura, Oligo- 
Miocene is allochthonous; he is constituted by an alternation of sandstones and clays.

Neogene: Neogen sediments are very heterogeneous (marl, clay, sand and gravel). The Miocene is characterized by continental deposits of sandstone- marl and conglomerate reshaping essentially elements limestone, silexe and ferruginous pebbles Haddouche (2003). It has a considerable thickness between 700 and $1200 \mathrm{~m}$ in Merahna.

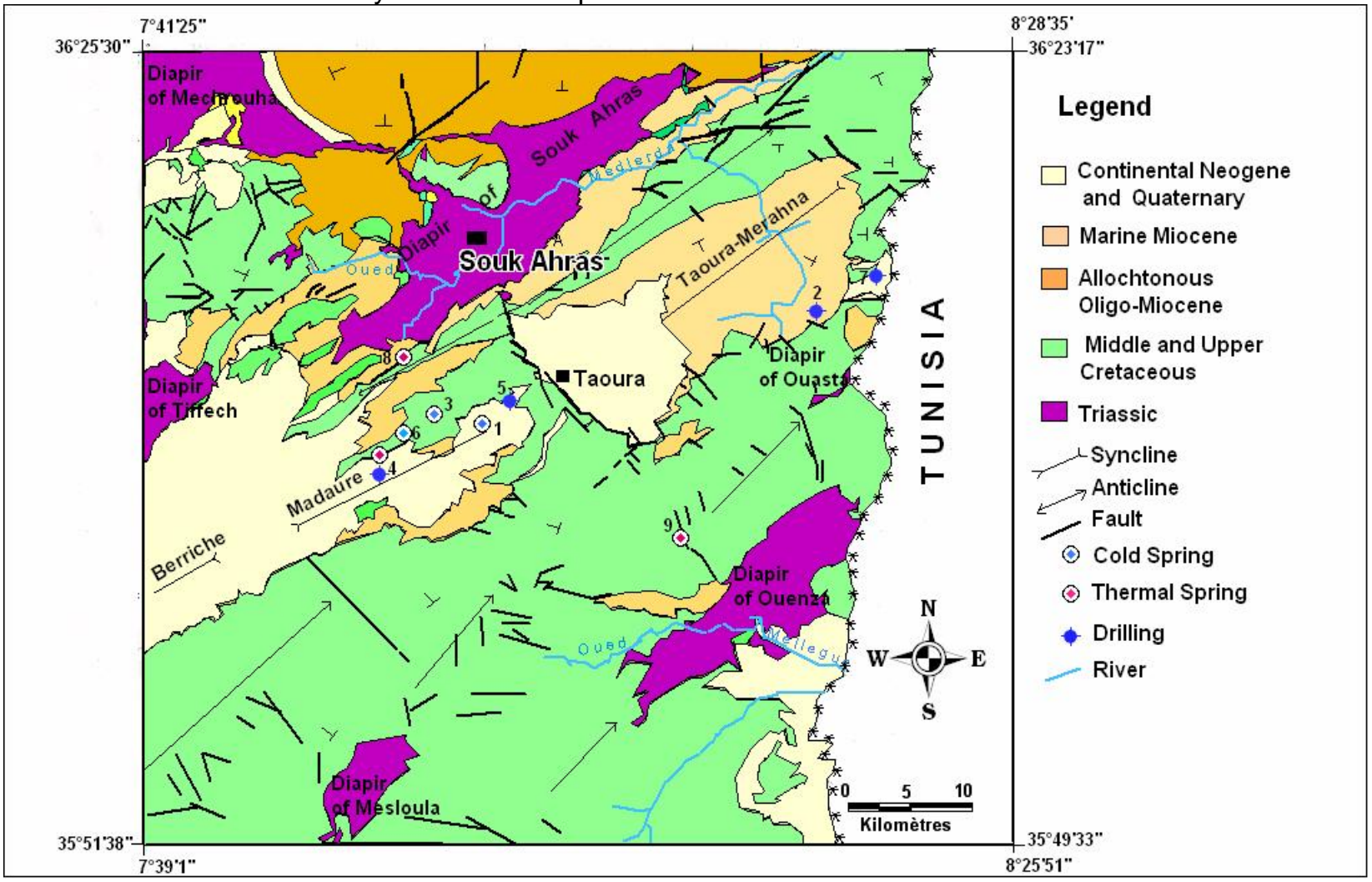

Fig. 2. Simplified geological map of the basin of Souk-Ahras Taoura showing the location of main water points. (Extract from the geological map of Souk-Ahras 1 / 200000, published in 1985 by the national mapping agency, Algiers).

Hydrogeological consequences: The groundwater basin contains a multilayer aquifer system composed of the fissural Miocene aquifer and the karstic aquifers of limestones Senonian and Lower Cretaceous.

Most springs are emerging in the fault zone between Madaure and Taoura (Fig. 2). The Miocene sandstone aquifer fissured updates to several sources for fractures in the area of Madaure. Ain Tamtmat, located $06 \mathrm{~km}$ south-west of the Taoura city is the largest emergence at a rate of around $08 \mathrm{~L} / \mathrm{s}$. Other sources have very low flow $(<04 \mathrm{~L} / \mathrm{s})$.

Horst structures in Campanian and Maastrichtian limestones with karst morphology (karren, dolines ...), promote infiltration of meteoric water and water circulation in the limestones. Possible loss of the affluents of the Medjerda collected between the mountains of southern Souk-Ahras could contribute to groundwater recharge Senonian.

The Campanian karst aquifer has several outlets with low flow (<5L/s) exception of Ain Guelib emerging with an average flow of 20L/s. Maastrichtian karst presents a highly developed epikarst in the chalky limestone. Among the outlets of the system Ain Legridjine is the largest with an average flow of 20L/s.

Both karstic systems of Senonian contain an important potential in water.

So, because of the irregularity of the precipitation and the heterogeneousness of the alluvionnaires deposits, the fissural Miocene aquifer and the karstic Senonian aquifers represent the main part of the resource in drinking water for the populations, as well 
as for the irrigation of the cultural lands and the industrial needs of the region.

The deep aquifer is recharged mainly by massive who have no outlets and by fissured land cover. It updates of hot springs located in the southwest of Souk-Ahras. Sources of Hammam Tassa emerge through the land of recoveries near the eastern flank of the anticline Jebel Tassa and Miocene sandstone, with a temperature between 39 and $41^{\circ} \mathrm{C}$ and a flow rate of $04 \mathrm{~L} / \mathrm{s}$. Other sources of very low flow (< 03L/s), including Ain El Damssa, emerging south of Hammam Tassa with temperatures around $28^{\circ} \mathrm{C}$ are mesothermal.

At emergence, the hot springs have a strong smell of sulfur, and gas bubbles due to an effect of air lift in karst reflecting a ventilated area (Figs. 3 and 4).

The deposition of travertine observed near Hammam Tassa indicates an outgassing of $\mathrm{CO}_{2}$ of deep origin.

Moreover, the sulfur deposited near the emergences would result of sulfate reduction by microorganisms.

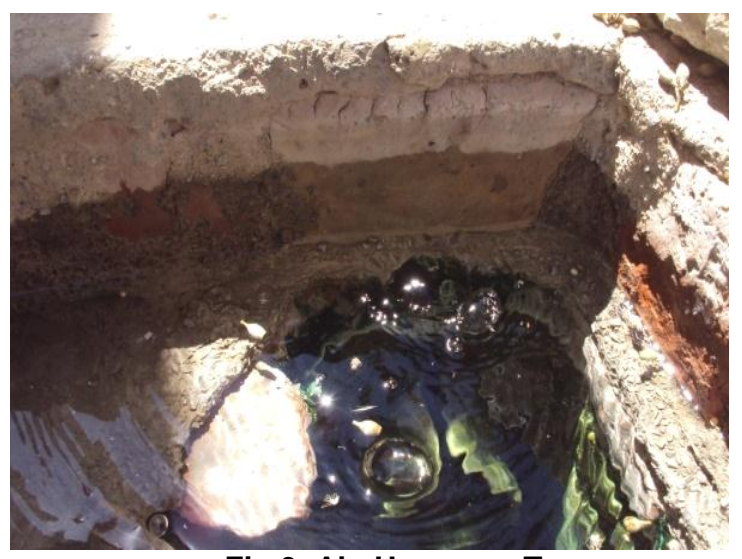

Fig.3. Ain Hammam Tassa.

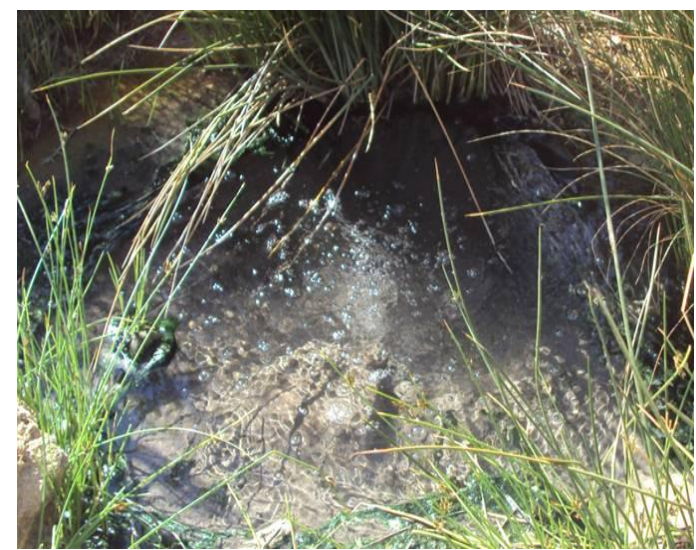

Fig.4. Ain El Damssa.

Photos: Bouroubi Ouadfel (Juin 2011).

MATERIALS AND METHODS

Several sampling campaigns of water sources and drillings operations, mostly karst, were performed for fundamental chemical analyzes. On a large number of water samples analyzed in 2007 in laboratory water chemistry (National Agency of Hydraulic Resources of Constantine- Algeria), we considered nine (09) samples of water sources and boreholes of the various aquifers for which we have complete data. The physical parameters and physico-chemical, temperature, $\mathrm{pH}$ and electrical conductivity were measured in situ using a thermometer, $\mathrm{pH}$ meter and conductivity meter mark HANNA (Tables 1 and 2). The calcium and magnesium ions were analyzed by continuous-flow spectrometry autoanalyzer. Sodium and potassium were measured by flame photometry. Bicarbonates were analyzed by volume, sulfate by turbidimetric, chloride and nitrate were assayed by colorimetric autoanalyzer continuous flow, strontium was analyzed by ICP-MS Jobin Yvon32 at the National Research Centre Nuclear Algiers.

Table1. Physical and physico-chemical water sources.

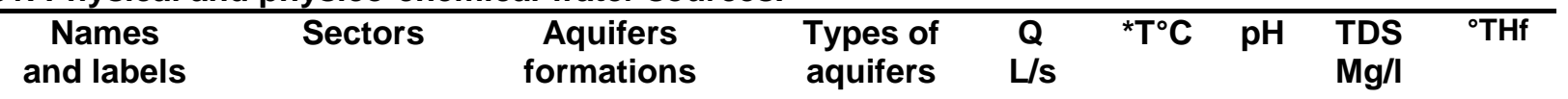

$\begin{array}{llllccccc}\text { Ain Tamtmat (1) } & \text { Madaure } & \text { Miocene } & \text { Fissural } & 8 & 17 & 7.3 & 764 & 42 \\ \text { Ain Legridjine (3) } & \text { Madaure } & \text { Maastrichtian } & \text { Karst } & 20 & 18.5 & 7.2 & 814 & 47 \\ \text { Ain Guelib (6) } & \text { Madaure } & \text { Campanian } & \text { Karst } & 20 & 20 & 7.1 & 1215 & 66 \\ \text { Hammam Tassa } & \text { Souk- } & \text { Lower } & & 4.5 & * 40 & 5.9 & 2407 & 84 \\ \text { (8) El Damssa } & \text { Ahras } & \text { Cretaceous } & \text { Hydrothermal } & 2 & 28.1 & 5.9 & 5062 & 173 \\ \text { Ain El } & \text { Taoura } & \text { Lower } & \text { Hydrothermal } & & & 2 & & \\ \text { (9) } & & \text { Cretaceous } & & & & & & \end{array}$

Q: average flow; *average temperature 
Am. J. Sci. Ind. Res., 2012, 3(5): 305-314

Table2. Physical and physico-chemical water drillings.

\begin{tabular}{|c|c|c|c|c|c|c|c|c|c|c|}
\hline & Labels & Sectors & $\begin{array}{c}\text { Aquifers } \\
\text { formations }\end{array}$ & $\begin{array}{l}\text { Depth } \\
(\mathrm{m})\end{array}$ & $\begin{array}{c}Q \\
L / S\end{array}$ & $\begin{array}{c}Z \\
(m)\end{array}$ & $\mathrm{T}^{\circ} \mathrm{C}$ & $\mathrm{pH}$ & $\begin{array}{l}\text { TDS } \\
\mathrm{mg} / \mathrm{L}\end{array}$ & THf \\
\hline \multirow{4}{*}{$\begin{array}{l}\text { Drilling } \\
\text { operation }\end{array}$} & (2) & Merahna & Miocene & 220 & 18 & 790 & 19 & 7.3 & 688 & 35 \\
\hline & (4) & Madaure & Maastrichtian & 106.5 & 25 & 812 & 20 & 7.3 & 1382 & 73 \\
\hline & (5) & Taoura & Maastrichtian & 244 & 24 & 850 & *24 & 7.3 & 717 & 44 \\
\hline & (7) & Merahna & Campanian & 102 & 25 & 825 & 21 & 7.4 & 735 & 44 \\
\hline
\end{tabular}

Q: average flow exploitation.

(The water temperature of the drill (5) varies from $3^{\circ} \mathrm{C}$ between the rainy and dry season).

(Data of pH,TDS and ${ }^{\circ} \mathrm{THf}$ are those of the low water in 2007).

The geochemical reference states provide access to water flow conditions in karst systems Bakalowicz (1979, 1995), Aunay et al., (2003). Thus, the calculated variables of the system $\mathrm{CO}_{2}-\mathrm{H}_{2} \mathrm{O}$ $\mathrm{CaCO}_{3}-\mathrm{MgCO}_{3}$, such as balancing the $\mathrm{pCO}_{2}$ and saturation indices of calcite, dolomite, gypsum have been estimated using the software charts 5.6 (Hydrogeology Laboratory of Avignon).

The mineral charge aquifers is analyzed through the concentration factor, the chloride ion is a reliable tracer of the state of concentration of a water
Barbiero et al., (1992), and an indicator of water mixtures El Achheb et al., (2003). To understand the origin of sulphates, to very low contents of variables, we have undertaken to use the contents of strontium Millot (1979) and the ratio $\mathrm{Sr}^{2+} / \mathrm{Ca}^{2+}$ Hsissou et al., (1996). Strontium was analyzed in samples of Hammam Tassa, Ain El Damssa and drilling in the waters (5) and (7) Senonian aquifers.

\section{RESULTS AND DISCUSSION}

Facies and geochemical profiles of water: (Chemical data are given in Tables 4 and 5, pages I and II).

Table3. Variables of the calco-carbonic system of sources and drillings of the karstic of Taoura in period low water 2007.

\begin{tabular}{ccccccc}
\hline Labels & $\begin{array}{c}\mathbf{p C O}_{2} \\
\left(10^{-1} \text { bar }\right)\end{array}$ & $\begin{array}{c}\mathbf{H}_{2} \mathbf{C O}_{3} \\
\text { eq }[\mathrm{mmol} / \mathrm{L}]\end{array}$ & Slc & Sld & $\mathbf{M g}^{2+} / \mathbf{C a}^{2+}$ & Slg \\
\hline $\mathbf{( 3 )}$ & 0.26 & 1.05 & 0.21 & -0.67 & 0.25 & -1.13 \\
$\mathbf{( 4 )}$ & 0.22 & 0.89 & 0.71 & 0.38 & 0.28 & -1.04 \\
$\mathbf{( 5 )}$ & 0.31 & 1.12 & 0,20 & -0.81 & 0.16 & -1.23 \\
$\mathbf{( 6 )}$ & 0.25 & 1.04 & 0,27 & -0.46 & 0.32 & -0.86 \\
$\mathbf{( 7 )}$ & 0.10 & 0.4 & 0,49 & -0.29 & 0.16 & -1.03 \\
$\mathbf{( 8 )}$ & 11.64 & 26.81 & -0.14 & -1.17 & 0.20 & -1.50 \\
$\mathbf{( 9 )}$ & 20.63 & 64.16 & 0.21 & -0.32 & 0.40 & -0.93 \\
\hline
\end{tabular}

SIc: Saturation indices of calcite; SId: Saturation indices of dolomite Slg: Saturation indices of gypse.

Geochemical data for water sources and drilling distinguish three types of water (Figs. 5 and 6): sodium-chlorinated (thermal aquifer), calcium sulphate (Campanian and Miocene aquifers), and bicarbonate-calcium (Maastrichtian aquifer). The facies of karst aquifers is different because of the travel time of the water, salt leaching Triassic and water temperatures. Overall, the profiles hydrogeochemical split water into three families, and show a variation of dissolved species (TDS, ${ }^{\circ} \mathrm{THF}$ ), directly related to the formations penetrated in the groundwater basin (Fig. 6). We distinguish:

- The thermal waters Ain El Damssa (9), Hammam Tassa (8) 
- The waters of Ain Guelib (6) and Ain Tamtmat (1)

- The water of Ain Legridjine (3)

In particular, Ain Hammam Tassa and Ain El Damssa differ from other waters by very high contents of alkaline chlorides, and high contents of calcium, magnesium and bicarbonates. The very high concentration of salts is related to the leaching of Triassic evaporitic land by the deep circulation of thermal waters.

Moreover, the elevation of total dissolved substances in a period of low water found in the waters of Hammam Tassa, Ain El Damssa and that of the drilling (5) of the Maastrichtian aquifer can be explained by a lack of contribution meteoric water associated with

a solubilization of carbonates, as indicated by the rise in calcium ions, bicarbonates, associated with a decrease of the magnesium (Table 5). In addition, nitrate contents assayed during the wet season and dry season are of interest both for water quality, as for how to recharge karst aquifers. Indeed, very high contents in the aquifer fissure dosed $(95 \mathrm{mg} / \mathrm{L}$ during the wet season and $67 \mathrm{mg} / \mathrm{L}$ in the dry season), reveal a man-made pollution affected the agricultural spraying. In addition, nitrate contents assayed during the wet season and dry season are of interest both for water quality, as for how to recharge karst aquifers. Indeed, the very high contents measured in the fissural aquifer

(95mg/L in wet season and $67 \mathrm{mg} / \mathrm{L}$ in dry season), reveal an anthropological pollution.

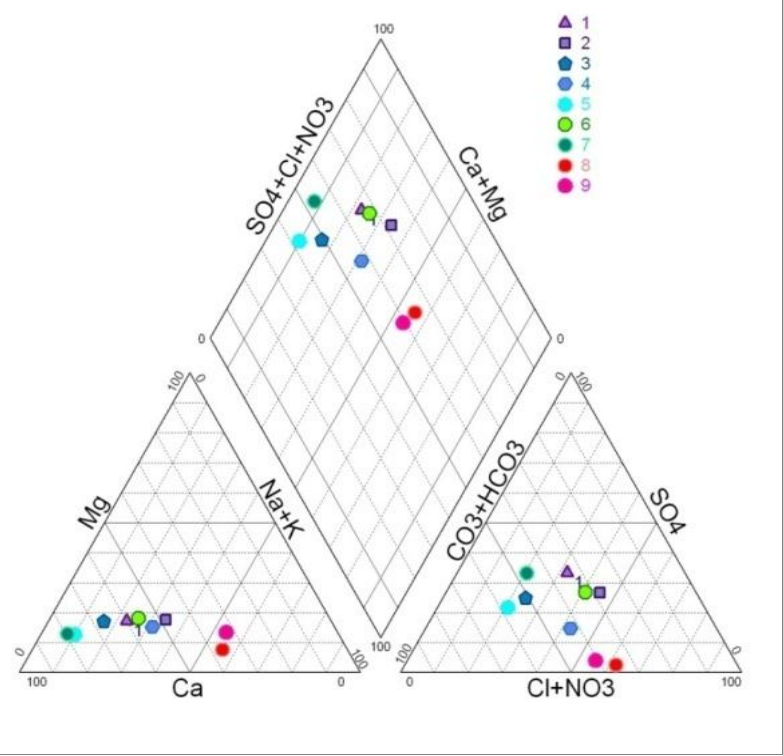

Fig.5. Geochemical facies of water sources and drillings of low water 2007.

For what interests karst aquifer flow system, the concentration found reversed in the dry season in the source Ain Guelib (32 and 58mg/L), water drilling (5) (32 and 52mg/L), and Hammam Tassa ( 1 and $4 \mathrm{mg} / \mathrm{L}$ ), informs a delayed infiltration (slow or delayed) in the zone under saturated system.

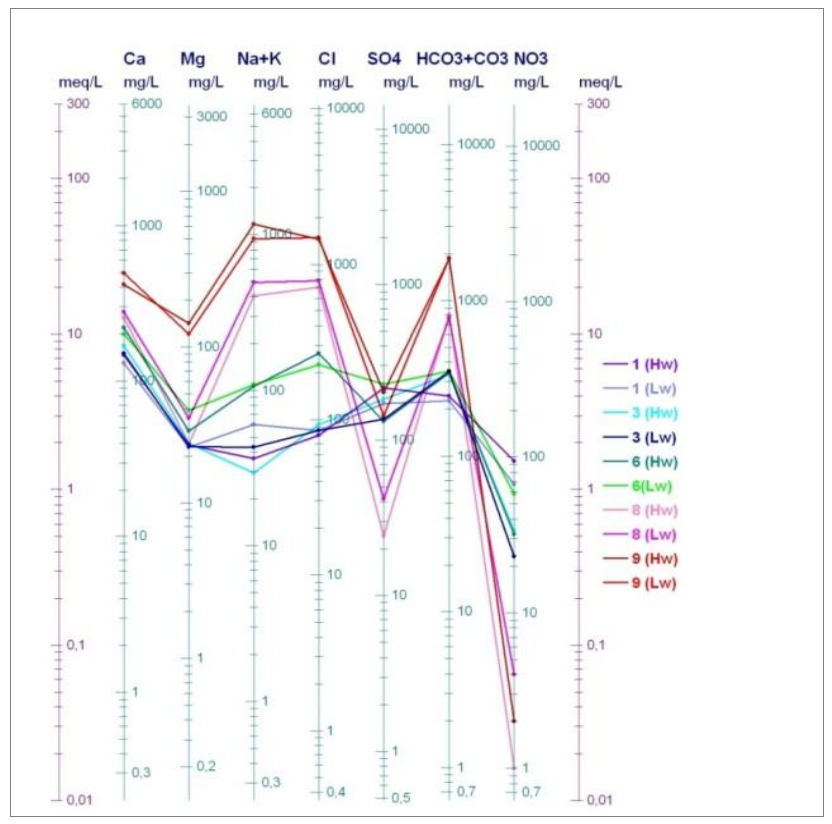

Fig.6. Geochemical Profiles of water springs in periods of high and low water 2007.

- Diagram $\mathrm{SO}_{4}{ }^{2-} / \mathrm{Cl}^{-}$vs $\mathrm{Mg}^{2+} / \mathrm{Na}^{+}$

The diagram $\mathrm{SO}_{4}{ }^{2-} / \mathrm{Cl}^{-}$versus $\mathrm{Mg}^{2+} / \mathrm{Na}^{+}$, substances evaporite is a tracing method to visualize the spatial evolution of species evaporites. All waters which are placed in the sodium chloride facies (Fig. 7). This distribution reflects the predominance of sodium and chloride on sulfates, especially for the deep aquifer and karst aquifers karstified carbonates Senonian. The analysis of the correlation between the ratios of molar concentrations $\mathrm{SO}_{4} / \mathrm{Cl}$ and that of $\mathrm{Mg} / \mathrm{Cl}$ gives the following information:

- Equation of the regression line: $\mathrm{C}_{\mathrm{SO} 4 / \mathrm{Cl}}=1.206$ * $\mathrm{C}_{\mathrm{Mg} / \mathrm{Na}}-0.103$

- Correlation coefficient $R=0.815$ and determination coefficient $R^{2}=0.665$.

The coefficient of determination indicates that the concentration of $\mathrm{Mg}^{2+} / \mathrm{Na}^{+}$explains $66,5 \%$ of the variance of the molar concentration $\mathrm{SO}_{4}{ }^{2-} / \mathrm{Cl}^{-}$. This result means that variables other than $\mathrm{C}_{\mathrm{Mg}} / \mathrm{Na}$ 
Table4. Chemistry data in period of hight water 2007. (Chemical analyses are given in $\mathrm{mg} / \mathrm{L}$ ).

\begin{tabular}{|c|c|c|c|c|c|c|c|c|c|c|c|c|c|}
\hline Name & $\begin{array}{c}\text { Nature of } \\
\text { points }\end{array}$ & Labels & $\begin{array}{c}\text { EC } \\
\mu \mathrm{s} / \mathrm{cm}\end{array}$ & $\mathbf{T}^{\circ} \mathbf{C}$ & $\mathrm{pH}$ & $\mathrm{Ca}^{2+}$ & $\mathrm{Mg}^{2+}$ & $\mathrm{Na}^{+}$ & $\mathrm{K}^{+}$ & $\mathrm{HCO}_{3}{ }^{-}$ & $\mathrm{Cl}^{-}$ & $\mathrm{NO}_{3}^{-}$ & $\mathrm{SO}_{4}{ }^{2-}$ \\
\hline Ain Tamtmat & $\mathrm{S}$ & $(1)$ & 1050 & 16.5 & 7.14 & 146.38 & 23.57 & 31.56 & 5.02 & 244 & 80 & 95 & 215 \\
\hline Bir Louhichi & $\mathrm{D}$ & (2) & 590 & 18 & 7.12 & 111.99 & 24.75 & 69.23 & 5.3 & 195.2 & 165 & 0 & 120 \\
\hline Ain Legridjine & $\mathrm{S}$ & (3) & 1150 & 18 & 7.07 & 168.16 & 24.07 & 24.69 & 4.53 & 335.5 & 92.4 & 34 & 182.8 \\
\hline D3 & $\mathrm{D}$ & $(4)$ & 1920 & 20 & 7.2 & 200.06 & 39.84 & 154.07 & 4.82 & 573.4 & 265 & 32 & 132 \\
\hline T7 & $\mathrm{D}$ & (5) & 830 & 21 & 7.2 & 121.3 & 11.37 & 17.93 & 2.86 & 292.8 & 50 & 32 & 154 \\
\hline Ain Guelib & $\mathrm{S}$ & $(6)$ & 950 & 18 & 7.06 & 220 & 28.82 & 101.4 & 3.98 & 341.6 & 265 & 32 & 132 \\
\hline MS1 & $\mathrm{D}$ & $(7)$ & 1100 & 21 & 6.75 & 152.65 & 14.89 & 15.55 & 2.29 & 292.8 & 50 & 43 & 164 \\
\hline Hammam Tassa & $\mathrm{S}$ & (8) & 2150 & 39.5 & 6.01 & 256.4 & 23.87 & 396.24 & 5.89 & 811.3 & 710 & 1 & 24 \\
\hline Ain El Damssa & $\mathrm{S}$ & (9) & 6380 & 26 & 6.4 & 416.05 & 141.99 & 1150 & 29 & 1848.3 & 1450 & 2 & 202 \\
\hline
\end{tabular}

S: Spring, D: Drilling.

Table5. Chemistry data in period of low water 2007. (Chemical analyses are given in mg/L).

\begin{tabular}{|c|c|c|c|c|c|c|c|c|c|c|c|c|c|}
\hline Name & $\begin{array}{c}\text { EC } \\
\mu s / c m\end{array}$ & $\mathrm{Ca}^{2+}$ & $\mathbf{M g}^{2+}$ & $\mathrm{Na}^{+}$ & $\mathrm{K}^{+}$ & $\mathrm{HCO}_{3}^{-}$ & $\mathrm{Cl}^{-}$ & $\mathrm{NO}_{3}{ }^{-}$ & $\mathrm{SO}_{4}{ }^{2-}$ & $\mathrm{Sr}^{2+}$ & $\begin{array}{c}\mathrm{Ca}^{2+} \\
10^{-3} \\
\text { moles } \\
\end{array}$ & $\begin{array}{c}\mathrm{Sr}^{2+} \\
10^{-3} \\
\text { moles }\end{array}$ & $\begin{array}{l}\mathrm{Sr}^{2+} / \mathrm{Ca}^{2+} \\
10^{-3} \text { or } \% \text { o }\end{array}$ \\
\hline Ain Tamtmat & 1090 & 130.69 & 22.73 & 52.51 & 8.02 & 225.7 & 85 & 67 & 172 & - & - & - & - \\
\hline Bir Louhichi & 870 & 102.37 & 22.51 & 79.89 & 5.45 & 176.9 & 160 & 9 & 132 & - & - & - & - \\
\hline Ain Legridjine & 1070 & 150.18 & 23 & 39.68 & 3.6 & 353.8 & 85 & 23 & 136 & - & - & - & - \\
\hline D3 & 1870 & 227 & 39 & 151.1 & 4 & 512.4 & 275 & 35 & 138 & - & - & - & - \\
\hline T7 & 860 & 151.5 & 15 & 22 & 1 & 335.5 & 40 & 52 & 100 & 0.17 & 3.783 & 0.0019 & 0.50 \\
\hline Ain Guelib & 1770 & 200.56 & 39.21 & 104.4 & 3.68 & 353.8 & 225 & 58 & 230 & - & - & - & - \\
\hline MS1 & 1010 & 129.38 & 13.27 & 34.97 & 2.98 & 250.1 & 100 & 46 & 78 & 0.076 & 5.010 & 0.00086 & 0.17 \\
\hline HammamTassa & 3760 & 277.24 & 35.09 & 475.6 & 18.4 & 774.7 & 780 & 4 & 42 & 0.92 & 3.811 & 0.0105 & 2.75 \\
\hline Ain El Damssa & 5730 & 494 & 121.6 & 920 & 30 & 1872 & 1480 & 0 & 144 & 5 & 12.38 & 0.057 & 4.60 \\
\hline
\end{tabular}


contribute to the observed variance of molar concentrations of $\mathrm{Mg}^{2+}$ and $\mathrm{Na}^{+}$.

The low value of the intercept corresponds to a net loss of water in $\mathrm{Mg}^{2+}$ and $\mathrm{Na}^{+}$, compared with what one must give the dissolution of chlorides. When not associated with evaporate minerals, especially halite, the alkali ions are generally provided by clays.

The limited analytical tools available for this study did not allow measuring the concentrations of silica $\left(\mathrm{SiO}_{2}\right)$. These data have helped to better characterize the deep circulation of thermal water, and therefore the potential power of the underlying karst aquifer. However, the fracturing of the Cretaceous carbonate to marly intercalations, is a significant index of the mobility of this water through marly. It can be argued that these waters are the result of a mixture in variable proportions between a thermal pole circulating in depth and a shallow pole corresponding to a direct local recharge, as is very frequent in hydrothermal sets.

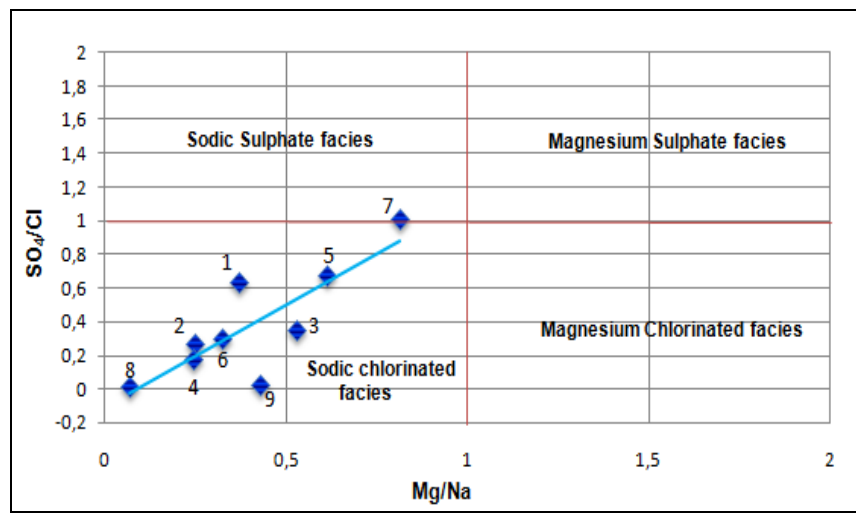

Fig.7. Geochemical facies across species evaporitic water sources and drillings

(Low water 2007).

Concentration diagram: The geochemical evolution of the salinity of the aquifer system of the basin Taoura described above, leads to consider a plot by the $\mathrm{Cl}^{-}$ion. The concentration factor (CF) is estimated from the classification of waters according to their contents of chlorides and compared with the lowest content. The concentration diagram is represented using the logarithm of the molalities of major ions versus the logarithm of the concentration factor.

The source Ain El Damssa was discarded because it is extremely charged (Table 4). In addition, there is a deposit of $\mathrm{NaCl}$ around the emergence which springs carbonates in favor of an accident North South.
With regard to other waters, the ranking of major ions molalities give in order of importance: $\mathrm{HCO}_{3}$ and $\mathrm{Ca}^{2+}>\mathrm{Cl}^{-}>\mathrm{Na}^{+}>\mathrm{Mg}^{2+}$ and $\mathrm{SO}_{4}^{2-}$.

The straight lines correlation of major ions $\left(\mathrm{Ca}^{2+}\right.$, $\mathrm{Mg}^{2+} \mathrm{Na}^{+}, \mathrm{HCO}_{3}^{-}$, and $\left.\mathrm{SO}_{4}{ }^{2-}\right)$, with the concentration factor (Fig. 8), all have a slope of less than 1 and a coefficient of determination between 0.35 and 0.96 .

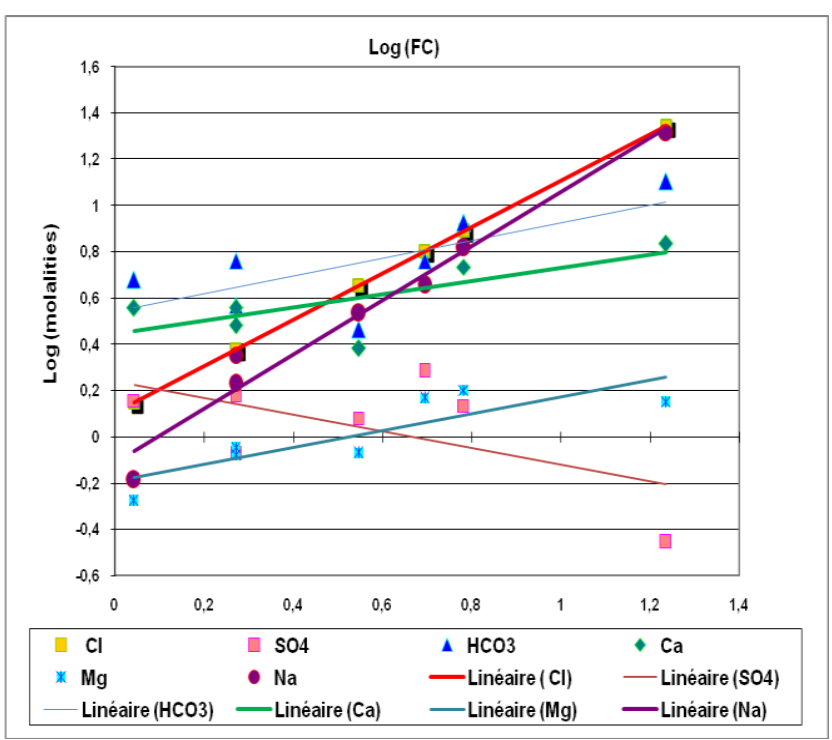

Fig.8. Concentration diagram of waters of springs and drillings (Low Waters 2007).

The regression of the sodium which joins that of chlorides, presents the most coefficient of determination (0.96). This distribution indicates that the concentration of sodium comes from the dissolution of halite.

The intersection of the lines of calcium and bicarbonate with that of chloride is a strong indication on the evaporating power and balances governed by the amount of $\mathrm{CO}_{2}$ aq subsurface.

The shape of the line of $\mathrm{Mg}^{2+}$ indicates two origins of this substance, one of the carbonate minerals and other evaporite minerals. It is intersected by the sulfates oriented opposite to the chlorides. This representation reveals a source of magnesium both different and common with that of sulphates. The mineral may provide these ions is the kainite $\mathrm{KMgCl}$ $\left(\mathrm{SO}_{4}\right) 3 \mathrm{H}_{2} \mathrm{O}$.

Tracing approach of sulfates by the strontium: We have seen in the geological context salt strontium $\mathrm{SrSO}_{4}$ exists in the fillings of fractures of carbonates. Strontium found in traces in water is a marker of potential natural gypsum or anhydrite, and may 
exceptionally be used for the characterization of hydrothermal karst.

The strontium concentration varies from 0.076 to $5 \mathrm{mg} / \mathrm{L}$ (Table 5). The highest $(0.92$ and $5 \mathrm{mg} / \mathrm{L})$ correspond to the thermal waters Ain Hammam Tassa and Ain El Damssa. The very low content $(0.076 \mathrm{mg} / \mathrm{L})$ belongs to water drilling (7) (Campanian aquifer) and low content $(0.17 \mathrm{mg} / \mathrm{L})$ corresponds to the water of the drilling (5) draining the Maastrichtian aquifer. Thus, strontium does not appear in trace amounts in the different waters analyzed.

The molar concentration ratio $\mathrm{Sr}^{2+} / \mathrm{Ca}^{2+}$, obviously distinguishes the thermal waters (2.75 and $4.6 \%)$, water boreholes (7) and (5) (0.17 and $0.5 \%$ ) Senonian aquifer (Table 5). The high strontium contents of thermal waters poor in sulphate and sodium chloride type, suggesting a strong reduction of this ion by sulphate-reducing bacteria. This is confirmed by field observations documenting a strong sulfur smell given off by the waters to the emergence and deposition of this substance around the springs. In addition, high contents of strontium would demonstrate the diversity of evaporite rocks, alteration and geochemical heat before its emergence, and a long residence time in the saturated zone. Geochemical mechanisms made between deep water circulation and evaporitic clays being governed by a mixture of water resulting in formation of salts such as $\mathrm{CaCO} 3, \mathrm{MgSO}_{4}$.

The ratio of the molar concentration of strontium sulfates reported that drilling (5) $(0.5 \%$ ) is quite high given the geochemical facies bicarbonate-calcium waters. These data could reflect two types of mixing water: either a dilution of sulfate acquired through contact with evaporites injected into the limestone, or a possible mixing with thermal waters. Finally, water drilling (7), geochemical facies of sulfate -calcium but the value of $\mathrm{Sr}^{2+} / \mathrm{Ca}^{2+}(0.17 \%)$ is the lowest indicates the presence of evaporite extension low in carbonates sector Merahna northeast of the basin.

The limited number of samples is insufficient to better describe both the character corruption thermomineral water that relations between the deepest waters and direct recharge.

The geochemical and thermal differences observed between water points can result so either from mixtures in variable proportions with more superficial waters, or from in-depth different evolutions and from circulation in zones containing evaporites injected along major tectonic accidents. In all cases, the observed differences result from the compartmentalization of aquifers by the intense recent extensional tectonics and affects the whole region and all geological formations.

Variables calculated by the system $\mathrm{CO}_{2}-\mathrm{H}_{2} \mathrm{O}$ $\mathrm{CaCO}_{3}-\mathrm{MgCO}_{3}$ and by the gypsum: The saturation state of karst aquifers in times of low water shows particularly high partial pressures $\left(\mathrm{pCO}_{2}\right)$ for thermal springs Ain Hammam Tassa and Ain El Damssa. The important contributions of $\mathrm{CO}_{2}$ are of deep origin. They lead to state waters currently flowing in the Lower Cretaceous aquifer with high potential for dissolution of the saturated zone. This dissolution is setting up a special karstification growing from bottom to top along the major extensional accidents promoting both the diffusion of gases and the rise of deep thermal waters. On the surface, travertine near Hammam Tassa reflects the dissolution. The subsaturation in calcite and high $\mathrm{pCO}_{2}$, and low outgassing visible to the emergence, indicate that water flow occurs in networks in load (Table 3).

The saturation indices in calcite (SIc) all positive globally less than 0.5 the rest of the water reflects degassing water before they reach zones of emergence and/or with a mixture of seepage.

The net subsaturation in dolomite and low values of the molar ratio $\mathrm{Mg}^{2+} / \mathrm{Ca}^{2+}$ calculated for the majority of waters are explained by a significant amount of aqueous $\mathrm{CO}_{2}\left(\mathrm{H}_{2} \mathrm{CO}_{3}\right)$ acting on the equilibrium conditions of the water. This translates into a $\mathrm{CO}_{2}$ degassing and formation of calcium salt $\mathrm{CaCO}_{3}$; this fact induces water circulation in aerated medium generated by the karstification of extensional fractures. Water of drilling (4) evolves to a supersaturation of dolomite and the Hammam Tassa is distinguished from all waters by a sharp supersaturation in dolomite.

The saturation indices in gypsum very negative for all waters and low sulfate concentrations (Table 3), seem to indicate, first, a sulfate reduction by microorganisms (sulfate-reducing bacteria), and moreover, the formation of anhydrite.

\section{CONCLUSION:}

In spite of some works which made reference to the balneology of waters, no hydrogeologic datum allowed to envisage that a real hydrothermal karstification was able to develop in these carbonated rocks. This hydrothermal karstification confers on the deep aquifer of the remarkable hydraulic properties: a storage capacity in saturated zone well above that of 
a fractured aquifer and a high hydraulic conductivity. These properties and the little numerous thermal emergences and low flows (approximately 20L/s total), presumably leading to a discharge of thermal waters in the overlying aquifers (Senonian and Miocene).

Finally, the resource in water of the fissural aquifer and karstic Senonian being particularly sensitive to pollution, a plan for their sustainable management and protection is very necessary.

\section{ACKNOWLEDGEMENTS:}

This work was made possible through the collaboration of the National Agency of Hydraulic Resources Algeria

\section{REFERENCES}

Aunay, B., Dörfliger, N., Le Strat, P., Ladouche, B and Bakalowicz, M (2003). Evolution géol ogique, Mise en place de la karstification et thermalisme des aquifères karstique

périméditerranéens. Exemple du karst des Corbières d'Opoul. Colloque "Circulations Hydrothermales en terrains calcaires", $10^{\text {ème }}$ journée technique. Carcassonne, CFH-AlH, 15-22.

Baaouague, A (2010). Les argiles de la région de SoukAhras: Identification, caractérisation, cartographie et impact sur l'environnement. Magister, Université d'Annaba, $126 \mathrm{p}$.

Bakalowicz, M (1979). Contribution de la géochimie des eaux à la connaissance de l'aquifère karstiqueet de la karstification. Thèse Paris VI, $269 \mathrm{p}$.

Bakalowicz, M., Ford D.C., Miller, T., Palmer, A.N. and Palmer, M.V (1989). Thermal genesis Of dissolution caves in the Black Hills, South Dakota, Geol. Soc. America Bull, pp 99, 729-738.

Bakalowicz, M (1995). La zone d'infiltration des aquifères karstique. Méthodes d'étude.Structure et fonctionnement. Hydrogéologie, pp 4, 3-21.

Barbiero, L., and Valles, V (1992). Aspects géochimiques de l'alcalinisation des sols dans la vallée du Dallol
Bosso (République du Niger). Cahiers de I'ORSTOM, série pédologie, 27(2):143-152.

Bouroubi, Y (2009). Étude hydrogéologique du synclinal de la Taoura. Fonctionnement et évaluation des ressources en eau souterraine. Magister, Université de Constantine, $184 \mathrm{p}$.

El Achheb, A., Mania, J. And Mudry, J ( 2003). Mécanismes d'acquisitions de la minéralisation des eaux souterraines dans le bassin Sahel-Doukala (Maroc occidental) approche par des traceurs hydrogéochimiques. Technologia de la intrusion de aqua de mar en acuiferos costeros : Paises Mediterraneos, Madrid, pp 113-123.

Emblanch, C., Charmoille, A., Jimenez, P., Andreo, B., Mudry, J., Bertrand, C., Batiot ,C and Millot,G (1979). Géochimie des eaux. Variations des teneurs en strontium dans les eaux du

Bassin de Paris. Note de Jean Carré et Maurice Pinta, O.R.S.T.O.M, C. R. Acad. Sc. Paris, t. 288 Série D: 1115-118.

Haddouche, O (2003). Contribution à l'étude géologique et gîtologique des minéralisations à $\mathrm{Pb}-\mathrm{Zn}, \mathrm{Fe}(\mathrm{Ba}-\mathrm{Sr})$ d'El Ouasta (Atlas saharien oriental, Algérie). Magister, Université d'Alger $108 \mathrm{p}$.

Hsissou, Y .,Chauve,P. Mania,J., Mangin,A., Bakalowicz,M and Gaiz,A (1996). Caractérisation des eaux de l'aquifère turonien du bassin du Tadla (Maroc) par le rapport des concentrations molaires $\mathrm{Sr}^{2+} / \mathrm{Ca}^{2+}$. Journal of Hydrology, Elsevier, $183: 445-451$.

Lastennet, R (2006). Variabilité du type et de la qualité de l'information issue du traçage naturel en fonction des caractéristiques des systèmes étudiés. Quelques exemples français et espagnols. Proceedings of the $8^{\text {th }}$ conference on limestone hydrogéology, Neuchâtel, 101-104.

Valles, V(2007). Support de cours d'hydrochimie. Laboratoire d'Hydrogéologie, d'Avignon. e-uapv.univavignon.fr.

Vila, J.M (1980). La chaîne d'Algérie orientale et des confins Algéro-Tunisiens. Thèse, Paris VI, $586 \mathrm{p}$. 